\title{
Quantifying the Seasonal and Interannual Variability of North American Isoprene Emissions Using Satellite Observations of the Formaldehyde Column
}

\section{Citation}

Palmer, Paul I., Dorian S. Abbot, Tzung-May Fu, Daniel J. Jacob, Kelly Chance, Thomas P. Kuruso, Alex Guenther, et al. 2006. Quantifying the seasonal and interannual variability of North American isoprene emissions using satellite observations of formaldehyde column. Journal of Geophysical Research 111: D12315.

\section{Published Version}

doi:10.1029/2005JD006689

\section{Permanent link}

http://nrs.harvard.edu/urn-3:HUL.InstRepos:3743790

\section{Terms of Use}

This article was downloaded from Harvard University's DASH repository, and is made available under the terms and conditions applicable to Other Posted Material, as set forth at http:// nrs.harvard.edu/urn-3:HUL.InstRepos:dash.current.terms-of-use\#LAA

\section{Share Your Story}

The Harvard community has made this article openly available.

Please share how this access benefits you. Submit a story. 


\title{
Quantifying the seasonal and interannual variability of North American isoprene emissions using satellite observations of the formaldehyde column
}

\author{
Paul I. Palmer, ${ }^{1,2}$ Dorian S. Abbot,${ }^{1}$ Tzung-May Fu, ${ }^{1}$ Daniel J. Jacob, ${ }^{1}$ \\ Kelly Chance, ${ }^{3}$ Thomas P. Kurosu, ${ }^{3}$ Alex Guenther, ${ }^{4}$ Christine Wiedinmyer, ${ }^{4}$ \\ Jenny C. Stanton, ${ }^{5}$ Michael J. Pilling, ${ }^{5}$ Shelley N. Pressley, ${ }^{6}$ Brian Lamb, ${ }^{6}$ \\ and Anne Louise Sumner ${ }^{7}$
}

Received 20 September 2005; revised 19 December 2005; accepted 14 February 2006; published 27 June 2006.

[1] Quantifying isoprene emissions using satellite observations of the formaldehyde (HCHO) columns is subject to errors involving the column retrieval and the assumed relationship between $\mathrm{HCHO}$ columns and isoprene emissions, taken here from the GEOSCHEM chemical transport model. Here we use a 6-year (1996-2001) HCHO column data set from the Global Ozone Monitoring Experiment (GOME) satellite instrument to (1) quantify these errors, (2) evaluate GOME-derived isoprene emissions with in situ flux measurements and a process-based emission inventory (Model of Emissions of Gases and Aerosols from Nature, MEGAN), and (3) investigate the factors driving the seasonal and interannual variability of North American isoprene emissions. The error in the GOME HCHO column retrieval is estimated to be $40 \%$. We use the Master Chemical Mechanism (MCM) to quantify the time-dependent $\mathrm{HCHO}$ production from isoprene, $\alpha-$ and $\beta$-pinenes, and methylbutenol and show that only emissions of isoprene are detectable by GOME. The time-dependent HCHO yield from isoprene oxidation calculated by MCM is $20-30 \%$ larger than in GEOS-CHEM. GOME-derived isoprene fluxes track the observed seasonal variation of in situ measurements at a Michigan forest site with a $-30 \%$ bias. The seasonal variation of North American isoprene emissions during 2001 inferred from GOME is similar to MEGAN, with GOME emissions typically $25 \%$ higher (lower) at the beginning (end) of the growing season. GOME and MEGAN both show a maximum over the southeastern United States, but they differ in the precise location. The observed interannual variability of this maximum is $20-30 \%$, depending on month. The MEGAN isoprene emission dependence on surface air temperature explains $75 \%$ of the month-to-month variability in GOME-derived isoprene emissions over the southeastern United States during May-September 1996-2001.

Citation: Palmer, P. I., et al. (2006), Quantifying the seasonal and interannual variability of North American isoprene emissions using satellite observations of the formaldehyde column, J. Geophys. Res., 111, D12315, doi:10.1029/2005JD006689.

\section{Introduction}

[2] Emissions of volatile organic compounds (VOCs) from the terrestrial biosphere have important implications

\footnotetext{
${ }^{1}$ Division of Engineering and Applied Sciences, Harvard University, Cambridge, Massachusetts, USA.

${ }^{2}$ Now at the School of Earth and Environment, University of Leeds, Leeds, UK.

${ }^{3}$ Harvard-Smithsonian Center for Astrophysics, Cambridge, Massachusetts, USA.

${ }^{4}$ National Center for Atmospheric Research, Boulder, Colorado, USA.

${ }^{5}$ Department of Chemistry, University of Leeds, Leeds, UK.

${ }^{6}$ Department of Civil and Environmental Engineering, Washington State University, Pullman, Washington, USA.

${ }^{7}$ Battelle, Columbus, Ohio, USA.

Copyright 2006 by the American Geophysical Union. 0148-0227/06/2005JD006689\$09.00
}

for tropospheric ozone $\left(\mathrm{O}_{3}\right)$ [Wang and Shallcross, 2000], organic aerosols [Claeys et al., 2004], and climate change [Sanderson et al., 2003]. Local VOC emission data, representative of scales less than $1 \mathrm{~km}$, are difficult to extrapolate, and consequently the magnitude and variability of these emissions is not well understood on continental scales. Standard emission inventories based on ecosystem data and emission factors [Guenther et al., 2005] are poorly constrained. We have shown previously that observations of formaldehyde ( $\mathrm{HCHO}$ ) columns from the Global Ozone Monitoring Experiment (GOME) satellite instrument [Chance et al., 2000] provide information to estimate biogenic VOC emissions, specifically isoprene emissions, on a global scale and with resolution of the order of $100 \mathrm{~km}$ [Palmer et al., 2003]. We examine here the quantitative value of these data for better understand- 
ing the variability of isoprene emissions during the North American growing season.

[3] Formaldehyde is a high yield product of VOC oxidation. Its atmospheric abundance is determined by a balance between production from the atmospheric oxidation of VOCs and losses from oxidation by the hydroxyl radical $(\mathrm{OH})$ and photolysis, resulting in a lifetime of a few hours. Formaldehyde columns measured from space therefore provide constraints on the underlying reactive VOC emissions. Over North America during summer the dominant VOC driving $\mathrm{HCHO}$ variability is biogenic isoprene. Palmer et al. [2003] showed good correspondence between HCHO columns measured by GOME and those simulated using the GEOS-CHEM chemical transport model (CTM) (Appendix A) with isoprene emissions from the Global Emission Inventory Activity (GEIA) [Guenther et al., 1995]. The GEOS-CHEM CTM had only a $10 \%$ mean positive bias against the GOME data over North America, though there were significant regional discrepancies.

[4] Abbot et al. [2003] extended this analysis to show that the seasonal variation of the $\mathrm{HCHO}$ columns measured by GOME over North America during summer 1997 is broadly consistent with understanding of the seasonal cycle of isoprene emission, and that the interannual variability in the GOME data can be explained partly by the temperature dependence of isoprene emission. Recent validation of GOME HCHO data using aircraft observations over Tennessee and eastern Texas confirmed the dominance of biogenic VOCs as precursors of $\mathrm{HCHO}$ over the spatial scales sampled by GOME $\left(40 \times 320 \mathrm{~km}^{2}\right)$ [Martin et al., 2004]. Shim et al. [2005] used GEOS-CHEM to conduct a global inversion of GOME HCHO column data from 1996 to 1997 to retrieve isoprene emissions from ten vegetation types and eight geographical regions. Over North America, GEOS-CHEM correlated well with GOME $(r=0.84)$ but required a $10 \%$ increase in annual isoprene emissions to minimize the bias relative to GOME, mainly due to increased emissions from temperate deciduous vegetation.

[5] The present work goes beyond the broad characterization of GOME HCHO data in previous studies [e.g., Abbot et al., 2003] to explore the value of these data for testing and improving process-based emission models of isoprene. Our focus will be on North America and our reference will be the new generation Model of Emissions of Gases and Aerosols from Nature (MEGAN) processbased inventory [Guenther et al., 2005]. This inventory incorporates the most recent knowledge about the functional dependence of isoprene emission on vegetation type, leaf age, temperature, and photosynthetic active radiation (PAR). Specific issues that we will address for quantitative interpretation of the GOME data in terms of isoprene emission include (1) the time-dependent $\mathrm{HCHO}$ yield from the oxidation of isoprene, (2) the potential role of other biogenic VOCs, such as monoterpenes and methylbutenol (MBO) to contribute toward HCHO column variability, and (3) the evaluation of the model-based relationship between $\mathrm{HCHO}$ column and isoprene emission using in situ observations. We will then exploit the GOME data to test the ability of MEGAN to reproduce the geographical, seasonal, and interannual variability in isoprene emission.

\section{Column Measurements of HCHO From GOME}

\subsection{Retrieval}

[6] The GOME instrument was launched onboard the ERS-2 satellite in April 1995. It measures backscattered solar radiation $(237-794 \mathrm{~nm})$ in the nadir (center and two sideways scans) with a $40 \times 320 \mathrm{~km}^{2}$ field of view. It is in a Sun-synchronous orbit with an equatorial local overpass time of 10:30, achieving global coverage within 3 days. Slant column abundances of HCHO are fitted in the 336$356 \mathrm{~nm}$ wavelength region with a mean column fitting uncertainty of $4 \times 10^{15}$ molec $\mathrm{cm}^{-2}$ [Chance et al., 2000]. These are converted to vertical HCHO columns using an air mass factor (AMF) formulation that accounts for the shape of the HCHO vertical profile and scattering processes from aerosols and clouds, in addition to Rayleigh scattering [Palmer et al., 2001; Martin et al., 2002]. Cloud fraction, height, and optical depth are retrieved from each GOME scene using the GOMECAT algorithm [Kurosu et al., 1999]. Aerosol scattering is computed using monthly mean 3-D aerosol fields and optical properties from the Global Ozone Chemistry Aerosol Radiation and Transport (GOCART) model [Chin et al., 2000, 2002; Ginoux et al., 2001]. The shape of the HCHO vertical profile is from the GEOS-CHEM model (Appendix A), for individual GOME scenes. UV albedos are from a climatological database [Koelemeijer et al., 2003]. Typical AMFs over North America range 0.7-1 [Palmer et al., 2001]. For the work shown here we use only data with an associated cloud fraction less than $40 \%$. A more restrictive cloud filter does not affect the HCHO column statistics [Palmer et al., 2001]. Figure 1 shows the HCHO slant columns for May-September 1996-2001 averaged over the $2^{\circ} \times 2.5^{\circ}$ GEOSCHEM model grid. There is a clear seasonal cycle each year with values peaking in midsummer, similar to the seasonal cycle shown by Abbot et al. [2003] for 1997. Further discussion and evaluation of the seasonal and interannual variability observed by GOME data is presented in sections 5 and 6.

\subsection{Correction of the Diffuser Plate Artifact}

[7] The solar irradiance measurements used for spectral fitting are taken by GOME every three days or less, a period denoted as a solar day. The diffuser plate of the GOME instrument introduces an artifact in the solar irradiance measurement that results in a global bias in the retrieved columns varying from solar day to solar day [Richter and Wagner, 2001; Richter et al., 2002]. Palmer et al. [2003] corrected this bias as the mean difference between observed versus GEOS-CHEM HCHO columns over the remote Pacific where columns are low and determined mainly by $\mathrm{CH}_{4}$ oxidation [Martin et al., 2002].

[8] Here, we improve the cleaning of the data set by accounting for the latitudinal and scan angle dependence of the diffuser plate artifact, and by better identifying and removing anomalous features. We identify "bad" solar days by computing the global mean slant $\mathrm{HCHO}$ column for each solar day and comparing it with the solar day means from 
May Jun Jul Aug Sep

1996

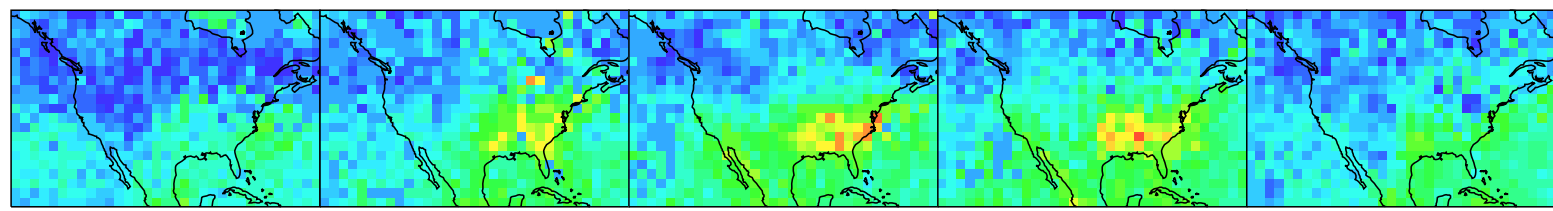

1997

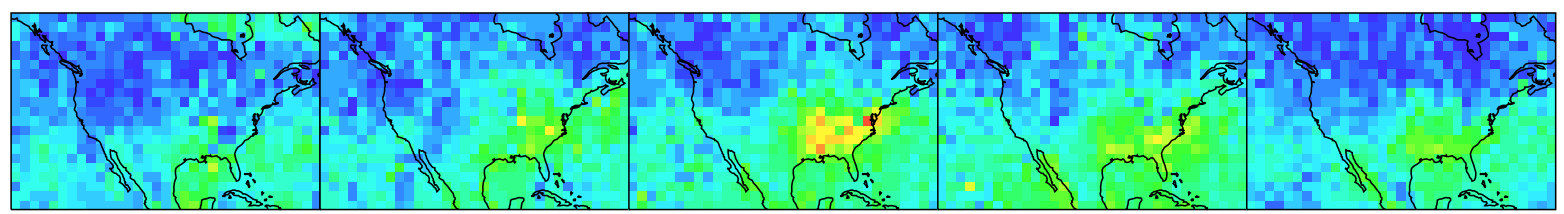

1998

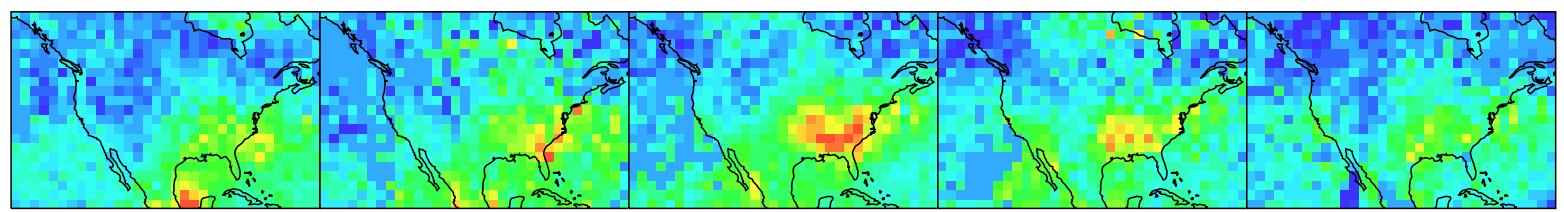

1999
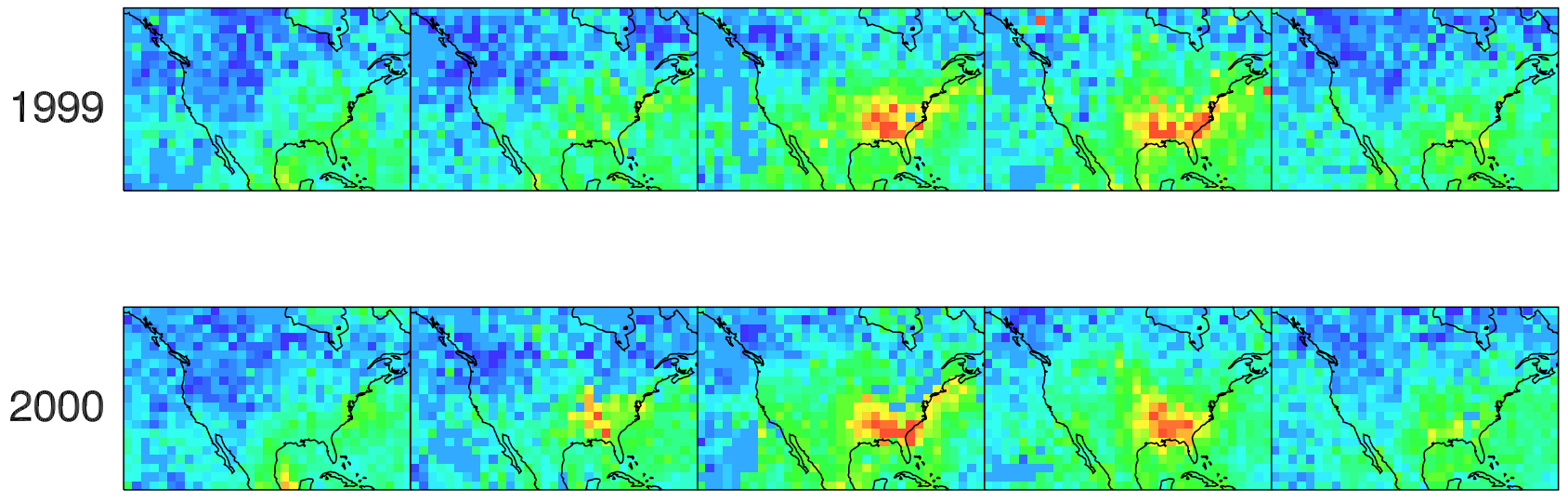

2001
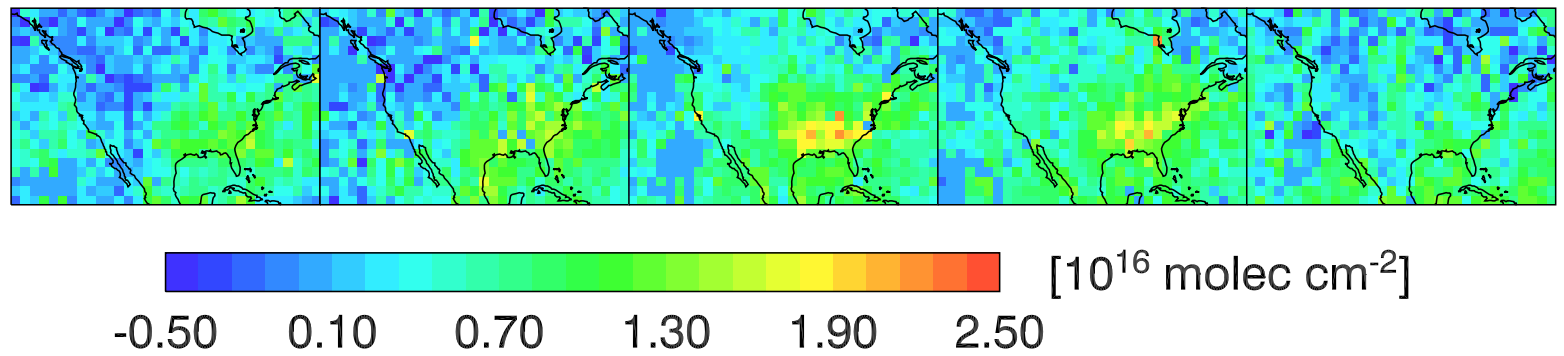

Figure 1. Monthly mean HCHO slant columns observed by GOME over North America for MaySeptember 1996-2001. The data are for 1000-1200 LT, averaged on a $2^{\circ} \times 2.5^{\circ}$ grid and for cloud cover $\leq 40 \%$. Each monthly mean grid point corresponds to an average of $20-30$ GOME observations. 
the rest of the month. Individual solar day means that are outside the mean \pm 1 standard deviation for that month are removed from the analysis. These anomalous means correspond to consecutive orbits that include large positive or negative columns that are many times the value of reasonable column abundances. Solar days with poor data coverage over the Pacific because of clouds are also removed from further analysis.

[9] The monthly mean corrections of the diffuser plate artifact range from -1.7 (August) to 4.2 (July) $\times 10^{15}$ molec $\mathrm{cm}^{-2}$, and are within the slant column fitting uncertainty [Chance et al., 2000]. The data cleaning removes $30 \%$ of the fitted HCHO slant columns. The resulting monthly means for 1997 are within 20\% of those shown by Abbot et al. [2003] but are less noisy.

\subsection{Error Analysis}

[10] Sources of error in the retrievals of vertical HCHO columns from GOME include (1) the slant column fitting, (2) the diffuser plate correction, and (3) the AMF calculation. Uncertainty in the slant column fitting is $4 \times 10^{15}$ molec $\mathrm{cm}^{-2}$ [Chance et al., 2000], which includes uncertainty in the $\mathrm{HCHO}$ absorption cross section. Uncertainty in the diffuser plate correction is likely much less. Sources of uncertainty in the AMF calculation include the UV albedo, the vertical distribution of $\mathrm{HCHO}$, and clouds and aerosols. The precision of the UV albedo database is 0.02 [Koelemeijer et al., 2003], corresponding to an AMF error of $8 \%$ [Palmer et al., 2001]. Model error on the vertical distribution of $\mathrm{HCHO}$ introduces a $10 \%$ error on the $\mathrm{AMF}$, based on comparison with aircraft observations over the southeast United States [Palmer et al., 2003]. Martin et al. [2003] estimated a range of AMF errors of $20-30 \%$ due to clouds. Scattering aerosols mixed with $\mathrm{HCHO}$ in the boundary layer generally decrease the AMF [Palmer et al., 2001], while absorbing aerosols have the opposite effect. The corresponding uncertainty in the AMF is less than 20\% [Palmer et al., 2001]. Overall we estimate an error on the AMF of about $30 \%$.

[11] The errors associated with spectral fitting $\left(4 \times 10^{15}\right.$ molec $\mathrm{cm}^{-2}$ on the slant column) and on the AMF $(30 \%)$ are added in quadrature. For a typical scene over the eastern United States with a vertical column of $2 \times 10^{16}$ molec cm $\mathrm{cm}^{-2}$ and an AMF of 0.7 , the over uncertainty on the vertical column is $9 \times 10^{15}$ molec $\mathrm{cm}^{-2}$.

\section{MEGAN Inventory for Isoprene Emission}

[12] We use the new generation Model of Emissions of Gases and Aerosols from Nature (MEGAN) [Guenther et al., 2005] as our best process-based emission inventory for comparison to the information from GOME. MEGAN is based on the earlier generation GEIA [Guenther et al., 1995] and BEIS [Guenther et al., 2000] inventories and includes extensive revisions to the base emissions factors and to the algorithms that describe the sensitivity to environmental factors. These revisions draw on recent field and greenhouse observations, and improvements to satellite and in situ land cover inventories.

[13] Isoprene emission $E$ in MEGAN is described as

$$
E=E_{0} \gamma_{L A I} \gamma_{T} \gamma_{A} \gamma_{P A R}
$$

where $E_{0}$ refers to the base emission factor for standard conditions (leaf area index $(\mathrm{LAI})=5$, surface air $T=303 \mathrm{~K}$,

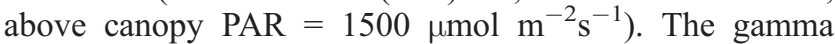
factors denote corrections to these standard conditions reflecting the LAI $\left(\gamma_{L A I}\right)$, leaf temperature $\left(\gamma_{T}\right)$, leaf age $\left(\gamma_{A}\right)$, and PAR $\left(\gamma_{P A R}\right)$. Details on $\gamma_{L A I}, \gamma_{A}$, and $\gamma_{P A R}$ are given by Guenther et al. [2005]. We elaborate here on $\gamma_{T}$ because it represents the principal source of day-to-day variability in the MEGAN inventory in summer. It is a function of both the current temperature and the mean local temperature for the past 15 days [Guenther et al., 1999]:

$$
\gamma_{T}=\frac{E_{o p t} C_{T_{2}} \exp \left(C_{T_{1}} x\right)}{C_{T_{2}}-C_{T_{1}}\left(1-\exp \left(C_{T_{2}} x\right)\right)},
$$

where $x=\left(T_{\text {opt }}^{-1}-T^{-1}\right) / R, T$ is the surface air temperature $(\mathrm{K}), R$ is the gas constant, $E_{\text {opt }}$ is the maximum value for $\gamma_{T}$, $T_{o p t}$ is the temperature at which $\gamma_{T}=E_{o p t}$, and $C_{T 1}=76$ and $C_{T 2}=160$ are empirical coefficients (units of $\ell^{-1} \mathrm{MPa}^{-1}$ $\mathrm{mol}$ ) representing the energy of activation and deactivation of emissions, respectively [Guenther et al., 2005]. These, and subsequent, coefficients take into account the variation of isoprene emission with surface temperature. This functional dependence exponentially increases isoprene emission with increasing surface air temperature up to a maximum at $T_{\text {opt }}$ followed by a rapid decline. Values of $E_{\text {opt }}$ and $T_{\text {opt }}$ are given by

$$
\begin{gathered}
E_{\text {opt }}=1.9 \exp \left(0.125\left(T_{15}-301\right)\right) \\
T_{\text {opt }}=316+0.5\left(T_{15}-301\right)
\end{gathered}
$$

where $T_{15}$ is the mean 24-hour average surface air temperature $(\mathrm{K})$ of the past 15 days.

[14] We drive MEGAN in GEOS-CHEM using assimilated surface air temperature and PAR (direct and diffuse) observations from the Global Modeling and Assimilation Office (GMAO) at NASA Goddard, and monthly mean LAI values for 2001 derived from the AVHRR satellite instrument [Buermann et al., 2002] and mapped on the $2 \times 2.5^{\circ}$ model grid. Annual isoprene emissions over North America from MEGAN are 10\% lower than from GEIA. In section 4 we also examine the potential contributions of monoterpenes and methylbutenol (MBO) to HCHO column observed by GOME. We use the GEIA inventory for monoterpenes [Guenther et al., 1995], and model MBO emissions following Guenther et al. [2000]. The sum of $\alpha-$ and $\beta$-pinenes accounts for $75 \%$ of total annual monoterpene emissions in North America [Guenther et al., 2000].

[15] Figure 2 shows the resulting seasonal course of isoprene, monoterpenes, and MBO emissions for the 2001 growing season, sampled at the GOME overpass time of 1000-1200 local time (LT). Emissions are maximum in July and August. Isoprene is emitted mainly from broadleaf trees, the most efficient including poplar, sweetgum, aspen, and oak. These tree types are mostly located in eastern North America with the highest density in the southeastern United States. Monoterpenes are primarily emitted by coniferous trees including pine, cedar, and redwood. These have the highest density in the northern United States and central Canada. MBO emissions are limited to selected conifer forests [Guenther et al., 2000]. On the continental 


\section{Isoprene Monoterpenes $\quad$ MBO}
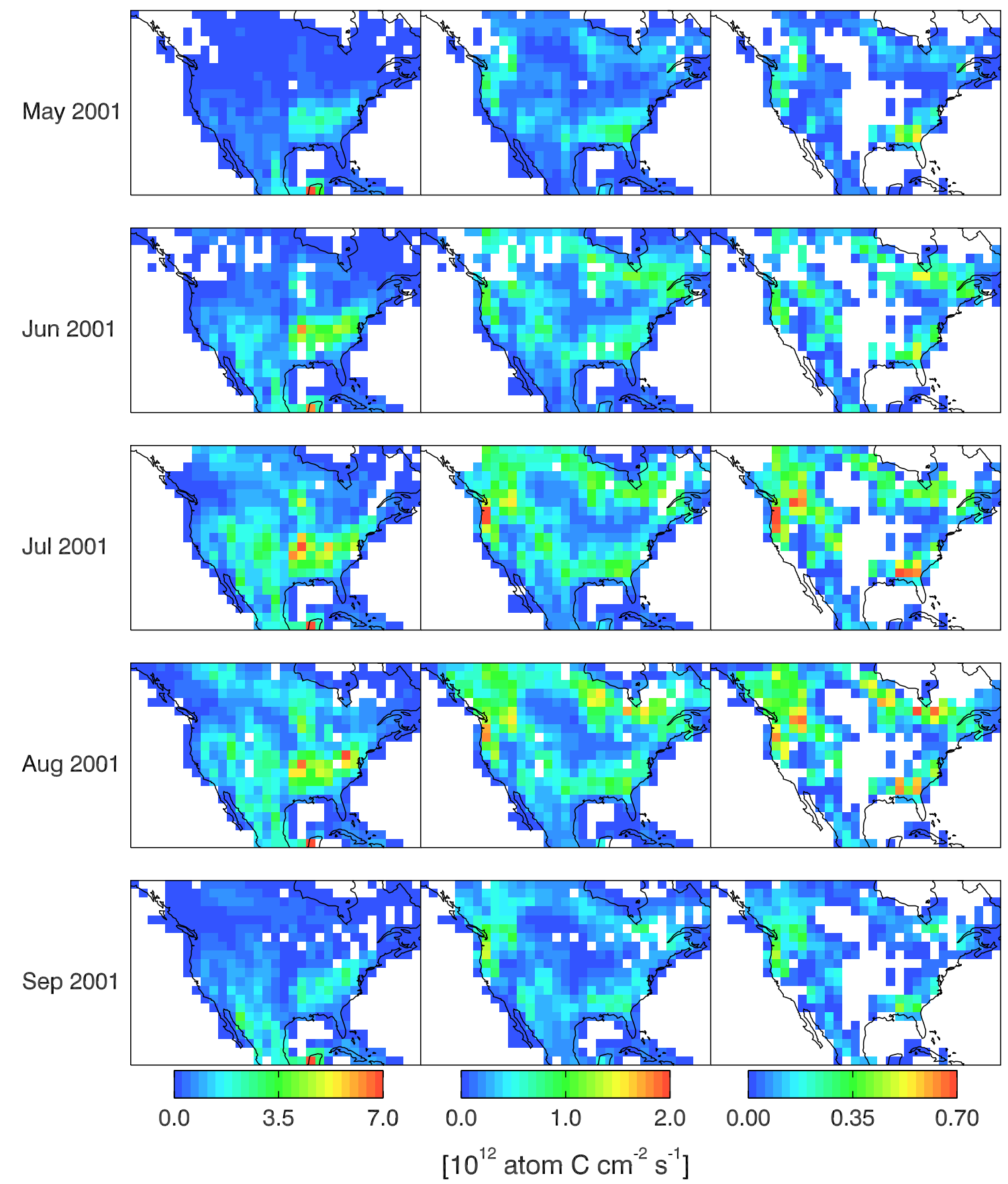

Figure 2. Monthly mean biogenic emissions as would be observed by GOME (1000-1200 LT) over North America. Isoprene emission estimates are from the MEGAN inventory, and monoterpenes and methylbutenol (MBO) emission estimates are from the GEIA and Guenther et al. [2000] inventories, respectively. White areas have no emissions. Note the differences in scales depending on species.

scale, isoprene emissions are about 3 times larger than monoterpenes and considerably higher than MBO.

\section{Relating Observed HCHO Columns to VOC Emissions}

[16] Palmer et al. [2003] previously described the theory for relating $\mathrm{HCHO}$ columns to reactive VOC emissions. In the absence of horizontal transport, the $\mathrm{HCHO}$ column $\Omega$ at steady state is linearly related to the sum of underlying VOC emissions $E_{i}$ scaled by their HCHO yields $Y_{i}$

$$
\Omega=\frac{1}{k_{\mathrm{HCHO}}} \sum_{i} Y_{i} E_{i},
$$

where $k_{\mathrm{HCHO}}$ is the loss rate constant for $\mathrm{HCHO}$ (reaction with $\mathrm{OH}$, photolysis) as applied to $\Omega$; reaction with $\mathrm{O}_{3}$ and 
$\mathrm{NO}_{3}$ represent minor $\mathrm{HCHO}$ losses during the day when GOME passes overhead. Horizontal transport smears this local relationship spatially to a degree that depends on the wind speed and the time lag between VOC emission and $\mathrm{HCHO}$ production. For isoprene the time lag is only a few hours, at least under high $\mathrm{NO}_{x}$ conditions (1 ppb), corresponding to a smearing length typically less than $100 \mathrm{~km}$, of the same order as the GOME field of view $(40 \times$ $320 \mathrm{~km}^{2}$ ). Formaldehyde columns in GEOS-CHEM at $2 \times$ $2.5^{\circ}$ resolution of the order of $200 \times 250 \mathrm{~km}^{2}$ show indeed a strong correlation with local isoprene emission [Palmer et al., 2003], consistent with the view that isoprene is the dominant driver of $\mathrm{HCHO}$ column variability and that the associated smearing is negligible.

[17] Palmer et al. [2003] used the GEOS-CHEM local relationship between isoprene emission and $\mathrm{HCHO}$ column, derived for North American quadrants, as a linear transfer function to infer local isoprene emissions from the GOME HCHO columns:

$$
\Omega=S E_{\text {isop }}+B
$$

where $S$ denotes the linear slope, $E_{\text {isop }}$ is the local isoprene emissions and $B$ denotes a background $\mathrm{HCHO}$ determined by the oxidation of other, generally, longer-lived VOCs. The slope $S$ depends on the model yield of $\mathrm{HCHO}$ from isoprene oxidation and the loss rate constant for column HCHO (equation (5)). The GEOS-CHEM chemical mechanism includes a relatively detailed treatment of isoprene oxidation chemistry, but there is still extensive lumping of oxidation intermediates [Horowitz et al., 1998]. We use here the fully explicit Master Chemical Mechanism (version 3.1, http:// mcm.leeds.ac.uk/MCM/) [Saunders et al., 2003; Jenkin et al., 2003], incorporating the latest information on VOC oxidation mechanisms, to evaluate the isoprene oxidation mechanism used in GEOS-CHEM. We also apply the MCM to calculate the time-dependent $\mathrm{HCHO}$ yields from $\alpha$ - and $\beta$-pinenes and MBO (not included in previous GEOSCHEM simulations) to assess their potential contributions to observed HCHO columns.

\subsection{Time-Dependent HCHO Yields From Biogenic VOCs}

[18] We present here MCM calculations of $\mathrm{HCHO}$ yields from the oxidation of isoprene, $\alpha$ - and $\beta$-pinenes, and MBO. These calculations are conducted in a box model (0-D) time-dependent simulation over a succession of diurnal cycles. The model is initialized at 9 LT for midlatitude summertime conditions with $1 \mathrm{ppb}$ of the VOC studied, $40 \mathrm{ppb} \mathrm{O}_{3}, 100 \mathrm{ppb} \mathrm{CO}$, and either 0.1 or $1 \mathrm{ppb}$ of $\mathrm{NO}_{x}$, which are assumed to represent low and high $\mathrm{NO}_{x}$ regimes, respectively. The VOC is allowed to decay while $\mathrm{O}_{3}, \mathrm{CO}$ and $\mathrm{NO}_{x}$ are held at their initial concentrations (following Zimmerman et al. [1978]). We show only results from the first two days. In practice only $\mathrm{HCHO}$ produced from the parent VOC within the first day can be related to the local VOC emission over the scale viewed by GOME.

\subsubsection{Isoprene}

[19] Isoprene $\left(\mathrm{C}_{5} \mathrm{H}_{8}\right)$ is oxidized by the $\mathrm{OH}$ radical on a timescale of less than 1 hour during daytime, producing organic peroxy radicals $\left(\mathrm{RO}_{2}\right)$. Under high $\mathrm{NO}_{x}$ conditions these $\mathrm{RO}_{2}$ radicals react with $\mathrm{NO}$, producing $\mathrm{HCHO}$ to- gether with methyl vinyl ketone (MVK) and methacrolein (MACR) as first-generation products [Sprengnether et al., 2002]. Subsequent oxidation by $\mathrm{OH}$ of MVK and MACR produces additional $\mathrm{HCHO}$ on a timescale of a few hours. The MCM estimates that $96 \%$ of the ultimate HCHO yield $\left(0.50 \mathrm{C}^{-1}\right)$ from the oxidation of isoprene under high- $\mathrm{NO}_{x}$ condition is produced on the first day (Figure $3 \mathrm{a}$ and Table 1). Results from the GEOS-CHEM mechanism [Palmer et al., 2003], also shown in Figure 3a for comparison, indicate an ultimate $\mathrm{HCHO}$ yield of $0.43 \mathrm{C}^{-1}$ with $90 \%$ of that yield reached within the first day.

[20] Under low $\mathrm{NO}_{x}$ conditions the production of $\mathrm{HCHO}$ is slower, as $\mathrm{RO}_{2}$ radicals react with $\mathrm{HO}_{2}$ to form organic peroxides that act as temporary reservoirs. The ensuing chemistry is not well understood but there is evidence from laboratory and field observations [Thornton et al., 2002; Hasson et al., 2004] that the organic peroxides are not terminal carbon sinks but generate $\mathrm{RO}_{2}$ and $\mathrm{RO}$ radicals by reaction with $\mathrm{OH}$ and photolysis on a timescale of a day. The MCM simulation with $0.1 \mathrm{ppb} \mathrm{NO}_{x}$ shows an ultimate $\mathrm{HCHO}$ yield of $0.47 \mathrm{C}^{-1}$, with $68 \%$ of that yield reached on the first day. The GEOS-CHEM chemical mechanism shows a lower ultimate yield under these low- $\mathrm{NO}_{x}$ conditions $\left(0.28 \mathrm{C}^{-1}\right)$ due to loss of carbon in the lumped products of organic peroxide reactions; similarly to the MCM, $66 \%$ of the ultimate yield is reached on the first day.

[21] Although the MCM mechanism is certainly more accurate than the GEOS-CHEM mechanism, there remains significant uncertainty. The $20-40 \%$ discrepancy in the time-dependent HCHO yields calculated by GEOS-CHEM and MCM provides an estimate for the related error in isoprene emission estimates from GOME observations via the model regression (equation (6)).

\subsubsection{The $\alpha$ - and $\beta$-pinenes and $\mathrm{MBO}$}

[22] Figures $3 \mathrm{~b}-3 \mathrm{~d}$ show the MCM-computed $\mathrm{HCHO}$ yields for $\alpha$ - and $\beta$-pinene and MBO. The main sinks of these VOCs are reaction with $\mathrm{OH}$ and $\mathrm{O}_{3}$, resulting in a lifetime of a few hours. Under high $\mathrm{NO}_{x}$ conditions, approximately $60 \%$ of the ultimate yield $\left(0.3 \mathrm{C}^{-1}\right)$ is reached by the end of day 1 , and under low- $\mathrm{NO}_{x}$ conditions $35-50 \%$ of the ultimate yield $\left(0.2 \mathrm{C}^{-1}\right)$ is realized for the same time period. Initial oxidation products for the pinenes include pinonaldehyde ( $\alpha$-pinene), nopinone ( $\beta$-pinene), $\mathrm{HCHO}$, and acetone. Initial oxidation products for $\mathrm{MBO}$ include HCHO, 2-hydroxy-2-methylpropanol, acetone, and glycolaldehyde. Long-lived intermediates such as acetone delay $\mathrm{HCHO}$ production, smearing the relationship of $\mathrm{HCHO}$ column to local VOC emissions.

[23] We see from Table 1 that the 1-day $\mathrm{HCHO}$ yields from oxidation of pinenes and $\mathrm{MBO}$ are only about one third those of isoprene. To determine the potential contribution of pinenes and $\mathrm{MBO}$ to $\mathrm{HCHO}$ columns in the GEOS-CHEM model, we parameterize their chemical decay to yield $\mathrm{HCHO}$ by fitting an exponential curve to the MCM results (Figure 3, high- $\mathrm{NO}_{x}$ regime). The fitted curve has an e-folding lifetime of 1.33 days and an ultimate $\mathrm{HCHO}$ yield of $0.3 \mathrm{C}^{-1}$. Using the high- $\mathrm{NO}_{x}$ regime provides an upper limit of the contribution of pinenes to $\mathrm{HCHO}$ production. The resulting contribution to the model HCHO column over North America is small (not shown), typically less than the slant column fitting uncertainty. We conclude that mono- 

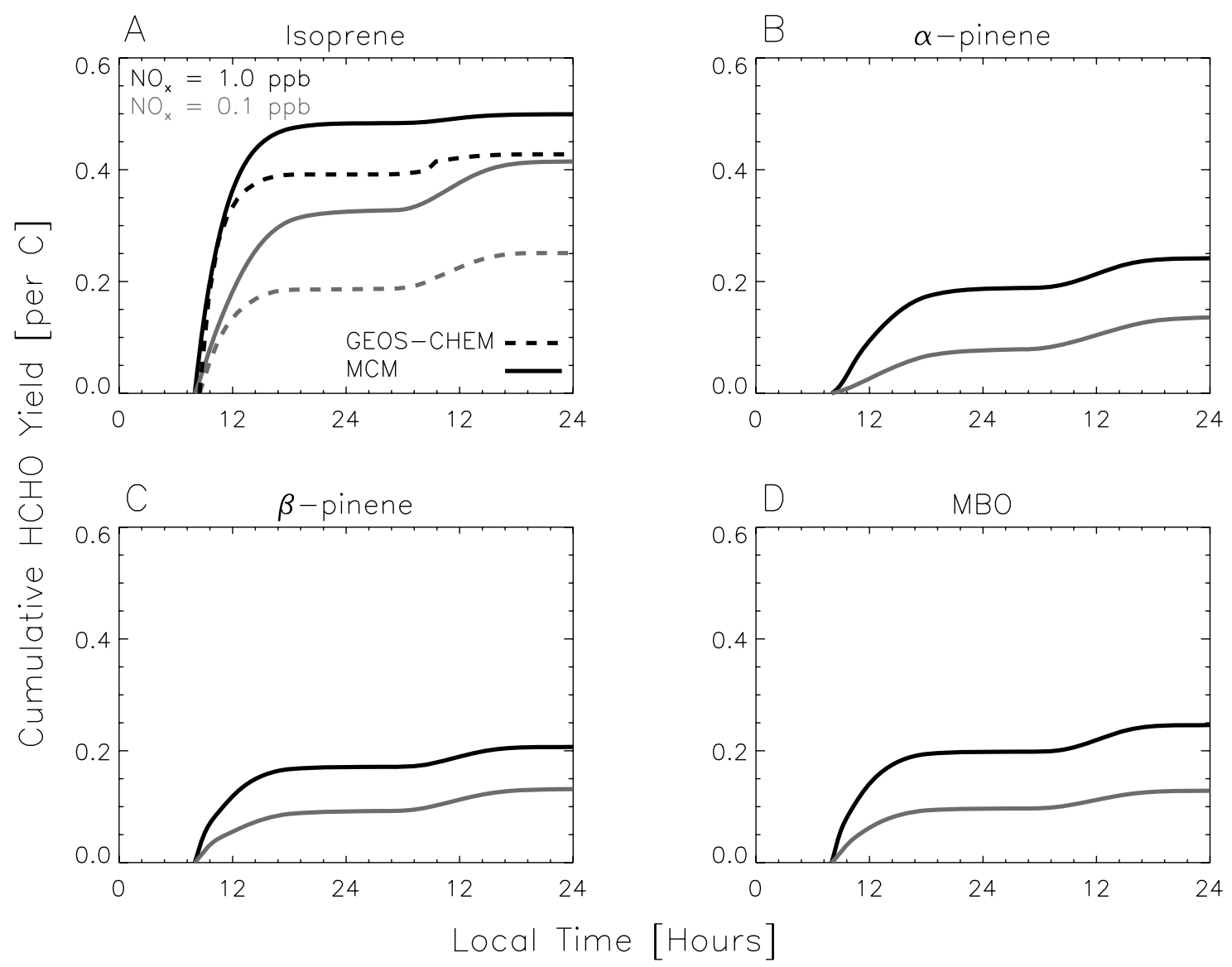

Figure 3. Time-dependent $\mathrm{HCHO}$ yields per carbon from the oxidation of isoprene, $\alpha$ - and $\beta$-pinenes, and methylbutenol (MBO). Values are computed using the Master Chemical Mechanism (version 3.1, http://mcm.leeds.ac.uk/MCM/) under high $\mathrm{NO}_{x}(1 \mathrm{ppb})$ and low $\mathrm{NO}_{x}(0.1 \mathrm{ppb})$ conditions. The calculations are initialized at 9 local time for midlatitude summertime conditions with $1 \mathrm{ppb}$ of the VOC studied, $40 \mathrm{ppb} \mathrm{O}_{3}, 100 \mathrm{ppb} \mathrm{CO}$, and either 0.1 or $1 \mathrm{ppb} \mathrm{NO}_{x}$, as described by Palmer et al. [2003]. The VOC is allowed to decay, while $\mathrm{O}_{3}, \mathrm{CO}$, and $\mathrm{NO}_{x}$ are held at their initial values. Also shown are the timedependent HCHO yields from the oxidation of isoprene computed by the GEOS-CHEM chemical mechanism [Palmer et al., 2003].

terpenes and MBO make little contribution to the $\mathrm{HCHO}$ column variability over North America seen by GOME.

\subsection{Model Regressions Between Isoprene Emissions and HCHO Columns}

[24] Palmer et al. [2003] used the GEOS-CHEM slopes of the local isoprene emission versus HCHO column linear regression (equation (6)), computed for July 1996 in North American quadrants separated at $\left(40^{\circ} \mathrm{N}, 110^{\circ} \mathrm{W}\right)$, to infer isoprene emissions from the GOME data. Here we examine the seasonal variation in that slope during the 2001 growing season as necessary to quantify seasonal variation in the isoprene emissions from the GOME data, and we also evaluate that model slope with field observations.

[25] Figure 4 shows the slopes $S$ computed using the GEOS-CHEM chemical mechanism for individual months during the 2001 growing season in the four North American quadrants. The correlation coefficients associated with these slopes are typically greater than 0.7 . Here and elsewhere, we use the reduced major axis method of linear regression, allowing for error in both correlated variables [Hirsch and
Gilroy, 1984]. The slopes are 50\% lower in summer (JuneAugust) than in the shoulder seasons (May, September), and are lower in the south than in the north, reflecting the photochemical lifetime of $\mathrm{HCHO}$ and the seasonal variation in column $\mathrm{O}_{3}$. The seasonal variation of isoprene emission is therefore amplified in the HCHO column observations.

Table 1. HCHO Yields per Carbon From the Oxidation of Isoprene, $\alpha$ - and $\beta$-pinenes, and $\mathrm{MBO}^{\mathrm{a}}$

\begin{tabular}{lcclcc}
\hline & \multicolumn{2}{c}{${\text { Yield, Day } 1^{\mathrm{b}}}$} & & \multicolumn{2}{c}{ Yield, Day $5^{\mathrm{b}}$} \\
\cline { 2 - 3 } \cline { 5 - 6 } Species & $1 \mathrm{ppb} \mathrm{NO}_{x}$ & $0.1 \mathrm{ppb} \mathrm{NO} n_{x}$ & & $1 \mathrm{ppb} \mathrm{NO} \mathrm{NO}_{x}$ & $0.1 \mathrm{ppb} \mathrm{NO}{ }_{x}$ \\
\hline Isoprene & $0.48(0.39)$ & $0.32(0.19)$ & & $0.50(0.43)$ & $0.47(0.29)$ \\
$\alpha$-pinene & 0.19 & 0.08 & & 0.31 & 0.23 \\
$\beta$-pinene & 0.17 & 0.09 & & 0.27 & 0.18 \\
MBO & 0.20 & 0.10 & & 0.35 & 0.21 \\
\hline
\end{tabular}

${ }^{\mathrm{a}} \mathrm{HCHO}$ yields are calculated using the Master Chemical Mechanism (version 3.1) [Saunders et al., 2003; Jenkin et al., 2003], as discussed in section 4. Numbers in parentheses refer to $\mathrm{HCHO}$ yields computed using the GEOS-CHEM chemical mechanism [Palmer et al., 2003].

${ }^{\mathrm{b}}$ The HCHO yield at day 1 is the yield at midnight of that day, and the yield at end of day 5 is taken in the text to be the ultimate yield. 


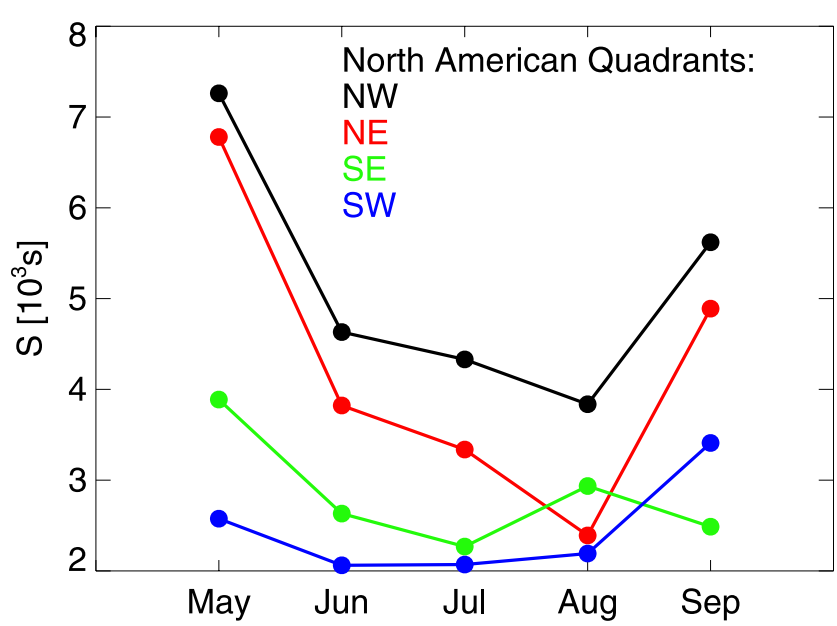

Figure 4. Slopes $S$ of the linear regression of the HCHO column versus isoprene emission (equation (6)) computed in the GEOS-CHEM model at 1000-1200 LT along the GOME orbit tracks and for cloud cover less than $40 \%$ and for individual months. Values are computed for individual North American quadrants with latitudinal and longitudinal divides at $40^{\circ} \mathrm{N}$ and $110^{\circ} \mathrm{W}$. Slopes are calculated using reduced major axis linear regression [Hirsch and Gilroy, 1984].

The isoprene lifetime in the shoulder seasons is still short enough that the correlations of $\mathrm{HCHO}$ and isoprene emissions remain strong.

[26] Palmer et al. [2003] interpreted the intercept of the isoprene:HCHO column regression as the background $\mathrm{HCHO}$ column due to long-lived VOCs (e.g., $\mathrm{CH}_{4}$ ). The mean intercept value is $4.8 \times 10^{15}$ molec $\mathrm{cm}^{-2}$, with largest values during mid-growing season in all quadrants. This seasonal variation likely represents an integrated background from the oxidation of VOCs with lifetimes too long for GOME to distinguish them individually.

[27] Concurrent observations of isoprene flux and $\mathrm{HCHO}$ concentration were made on 12 days during 11 July 11 to 20 August 1998 at the PROPHET mixed forest site located in northern Michigan $\left(42^{\circ} 30^{\prime} \mathrm{N}, 84^{\circ} 42^{\prime} \mathrm{W}\right.$; elevation $\left.238 \mathrm{~m}\right)$ [Sumner et al., 2001; Pressley et al., 2005]. We sample these observations between 1000 and 1200 LT, coinciding with the GOME overpass. Isoprene fluxes were measured by eddy correlation and range from 0.4 to $8.2 \times 10^{12}$ molec $\mathrm{cm}^{-2} \mathrm{~s}^{-1}$ over the 12-day period, with a mean value of $4.2 \times 10^{12}$ molec $\mathrm{cm}^{-2} \mathrm{~s}^{-1}$. We calculate HCHO columns from the observed surface concentrations by assuming an idealized exponentially decaying vertical profile of number density, with a scale height of $1 \mathrm{~km}$ based on aircraft observations of $\mathrm{HCHO}$ over the southeast United States [Fiore et al., 2002]. Using these assumptions, the measured $\mathrm{HCHO}$ surface concentrations (2-9 ppb) correspond to column abundances of $0.6-2.4 \times 10^{16}$ molec $\mathrm{cm}^{-2}$. The resulting slope (Figure 5) is $2.1 \times 10^{3} \mathrm{~s}$, which is $30 \%$ smaller than the mean GEOS-CHEM model slope for the Northeast in July-August 2001. The 30\% discrepancy between model and observed slopes should be regarded as consistent within the uncertainty in the analysis, e.g., taking into account uncertainties associated with the model oxida- tion mechanism and mixing depths. The lower slope in the PROPHET data could reflect a significant fetch over the Great Lakes.

\section{Seasonal Variation of GOME Isoprene Emission: Comparison With in Situ Observations and MEGAN}

\subsection{Local Comparison at the PROPHET Site}

[28] Isoprene flux measurements by Pressley et al. [2005] at the PROPHET site over the length of the 2001 growing season offer an opportunity to evaluate the isoprene emissions inferred from GOME. The measurements were made by eddy correlation with a mean uncertainty less than $40 \%$ [Pressley et al., 2005]. We sample these data at 1000$1200 \mathrm{LT}$, corresponding to the overpass time of the GOME satellite instrument. Figure 6 shows the seasonal time series of isoprene flux measurements, featuring an increase from leaf-out to early August followed by a sharp decline, with large day-to-day variability superimposed. MEGAN fluxes are within a factor of 2 of measurements $(r=0.55$, bias $=$ $-3 \times 10^{12}$ atom $\left.\mathrm{C} \mathrm{cm}^{-2} \mathrm{~s}^{-1}\right)$. Isoprene emissions estimated from GOME track well the seasonal course of isoprene flux but have more difficulty with day-to-day variability $(r=$ 0.30 , bias $=1.3 \times 10^{12}$ atom $\left.\mathrm{C} \mathrm{cm}^{-2} \mathrm{~s}^{-1}\right)$.

\subsection{Seasonal Variability on the Continental Scale}

[29] Monthly mean isoprene emissions calculated from GOME HCHO columns for the 2001 growing season over North America are shown in Figure 7 and compared to the corresponding MEGAN model values. There is strong coherence in the continental-scale seasonal variations with

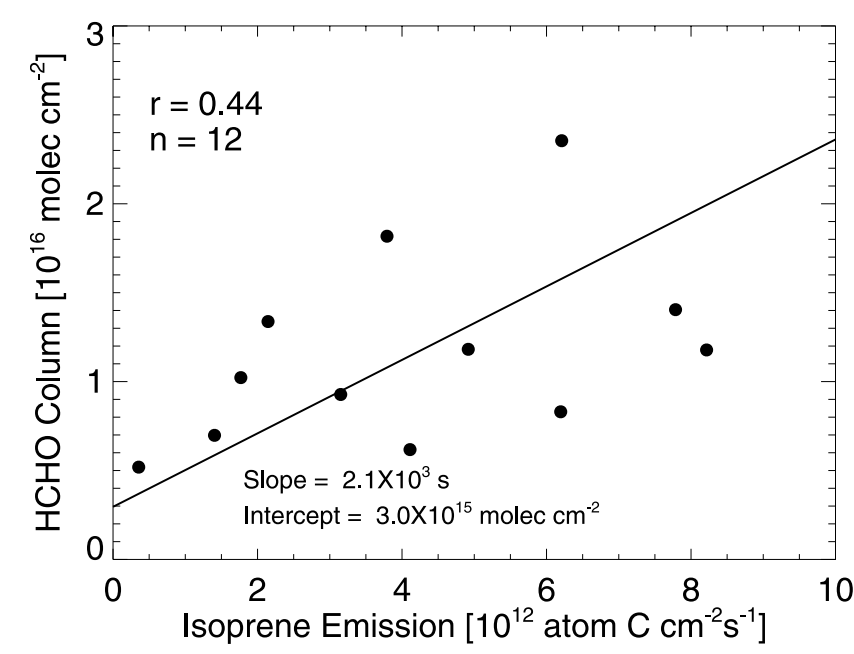

Figure 5. Relationship between $\mathrm{HCHO}$ and isoprene emission measured at the PROPHET forest site in northern Michigan $\left(42^{\circ} 30^{\prime} \mathrm{N}, 84^{\circ} 42^{\prime} \mathrm{W}\right.$; elevation $\left.238 \mathrm{~m}\right)$ for 12 days from 11 July to 20 August 1998 at 1000-1200 LT, as viewed by GOME. HCHO columns are calculated from the measured surface HCHO concentrations [Sumner et al., 2001] by assuming an exponentially decaying vertical profile of mixing ratio with a $1 \mathrm{~km}$ scale height. The Pearson correlation $r$, the number of points used to compute $r$, and the slope and intercept of the reduced major axis linear regression [Hirsch and Gilroy, 1984] are shown inset. 


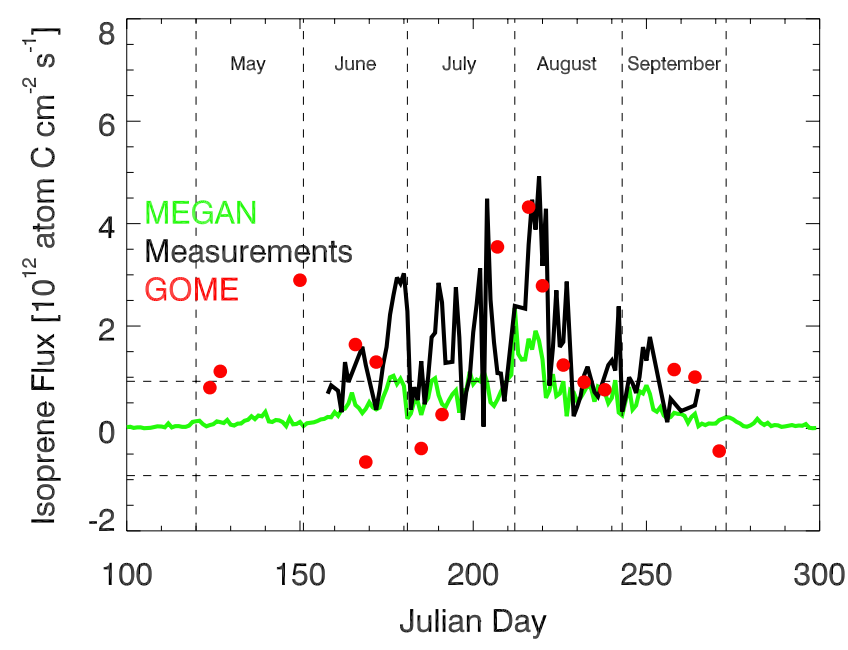

Figure 6. Isoprene fluxes at the PROPHET forest site, Michigan, as viewed by GOME (1000-1200 LT) during the 2001 growing season. Green and black lines denote MEGAN and measured isoprene fluxes, respectively. Red circles denote isoprene fluxes retrieved from GOME HCHO columns. Horizontal dashed lines denote uncertainty in the retrieved HCHO vertical columns (section 2).

values peaking in July-August when temperatures are highest. GOME is higher than MEGAN by $10-20 \%$ in early summer and lower by $30 \%$ than MEGAN in late summer. Palmer et al. [2003] previously found that GOME was $20 \%$ lower than GEIA isoprene emissions over North America during July 1996. This is consistent with differences between the GEIA and MEGAN inventories [Guenther et al., 2005]. Both MEGAN and GOME place the largest isoprene emissions over the southeastern US. MEGAN and GOME show a hot spot over the Ozarks oak forest in Missouri [Wiedinmyer et al., 2005]. GOME also shows large emission further east that are not evident in MEGAN.

[30] Abbot et al. [2003] showed a similar seasonal variation for for HCHO columns in 1997 but during that year HCHO remained high in September before declining rapidly in October. This is in part due to neglecting the timedependent slope $S$, which effectively reduces emissions during the shoulder months (Figure 4). As we show later other differences between 1997 and 2001 are an example of the large observed interannual variability in the seasonal cycle.

\section{Interannual Variability of GOME Isoprene Emissions}

[31] We examine interannual variability in isoprene emission over the 1996-2001 period using the GOME slant HCHO columns (Figure 1). We use monthly mean AMF fields from 2001 (Figure 7) to convert observed slant columns to vertical columns, and the monthly isoprene emission:HCHO column slopes (Figure 4) to convert the vertical columns to isoprene emissions. The interannual variation in AMF is likely to be much less than the seasonal variation $(8 \%)$. Interannual variation in the isoprene emission:HCHO column slopes (Figure 4) is also likely to be much smaller than the seasonal variation. Monthly mean vertical HCHO columns during 2001 calculated using monthly mean AMFs are within a few percent of those calculated using scene-specific AMFs (Figure 7).

[32] Figure 8 shows the isoprene emission calculated from the GOME slant column data (Figure 1). Isoprene emissions during summer 2001 are among the lowest in the 6-year period; the largest are for 1998-2000. For all years the GOME isoprene emissions over North America are largest in June-August, with values approaching noise levels outside this time period [Abbot et al., 2003]. Here, we estimate the monthly mean interannual variability as the one standard deviation about the 6-year monthly means. The percentage interannual variability of isoprene emissions for June, July, and August over 1996-2001 are 27\%, 22\%, and $35 \%$, respectively.

[33] To further explore this interannual variability we focus on the southeast United States $\left(32^{\circ}-38^{\circ} \mathrm{N}, 80^{\circ}-\right.$ $95^{\circ} \mathrm{W}$ ), where the $\mathrm{HCHO}$ columns are largest and the interannual variability is clearest. Mean seasonal variations of slant HCHO columns for this region are shown in Figure 9. Values for a particular year can depart from the 1996-2001 mean (black line) by more than 40\% for a particular month. The start of isoprene emissions over the southeastern United States is typically during mid to late May. The timing of the seasonal maximum varies from year to year, although it is always in July-August. All years show a rapid decline in September and a shutdown of isoprene emissions by the end of that month.

[34] Figure 10 correlates the monthly mean GOMEderived isoprene emissions for 1996-2001 over the southeastern United States with the corresponding monthly mean surface air temperature to investigate the extent to which temperature drives the variability observed by GOME. We use National Centers for Environmental Prediction (NCEP) surface air temperature because GMAO does not provide a consistent continuous data set over those six years. We find that the MEGAN dependence of isoprene emission on surface air temperature (equation (2)) explains more than $75 \%$ of the observed variance in the GOME-derived isoprene emissions when we use NCEP monthly mean temperatures to represent both the instantaneous temperature, $T$, and the mean 15-day temperature, $T_{15}$; acknowledging that equation (2) was designed primarily to simulate isoprene fluxes using surface air temperature on shorter timescales. Accounting for $T_{15}$ generally decreases emissions at temperatures below $298 \mathrm{~K}$ and introduces a stronger emission dependence on temperature above $295 \mathrm{~K}$ with the effect of increasing emissions above $298 \mathrm{~K}$.

[35] Fitting the activation and deactivation energy values $\left(C_{T_{1}}\right.$ and $\left.C_{T_{2}}\right)$ in equation (2) determines the rate at which isoprene emission responds to temperature. These are empirical coefficients with values of 76 and $160\left(\ell^{-1}\right.$ $\mathrm{MPa}^{-1}$ mol), respectively [Guenther et al., 2005]. We fit these coefficients to the ensemble of summertime GOME data. Fitted values of $C_{T_{1}}$ and $C_{T_{2}}$ with and without $T_{15}$ are 125 and 156, and 119 and $141\left(\ell^{-1} \mathrm{MPa}^{-1} \mathrm{~mol}\right)$, respectively. These fitted values do not improve significantly the correlation $(\mathrm{r}=0.87)$ between the GOME- 
MEGAN
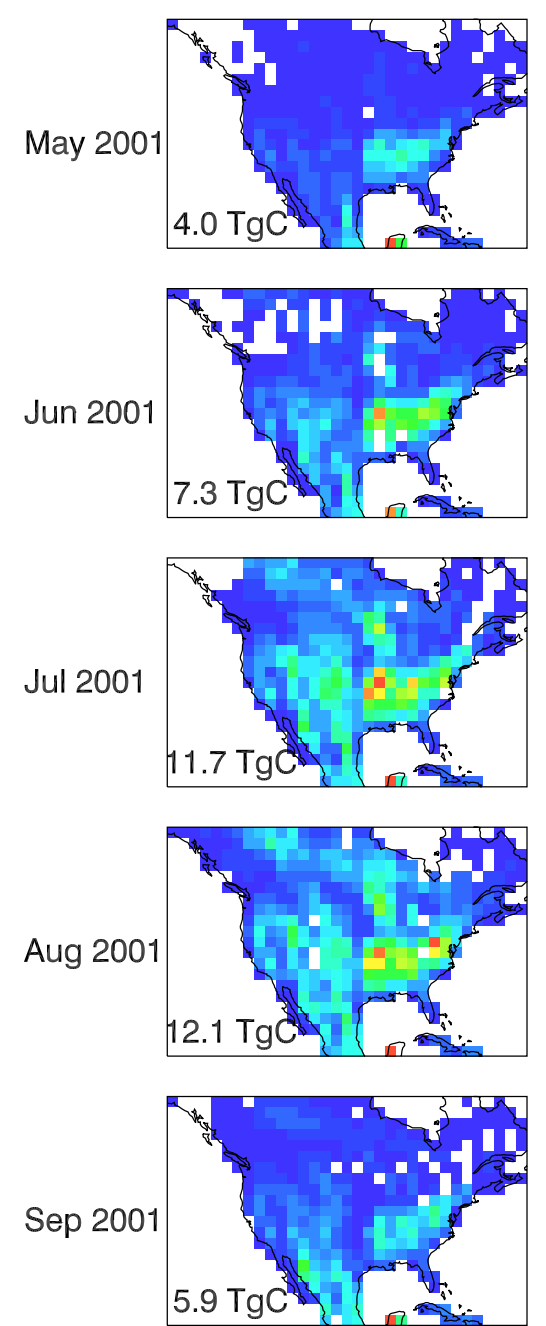

GOME
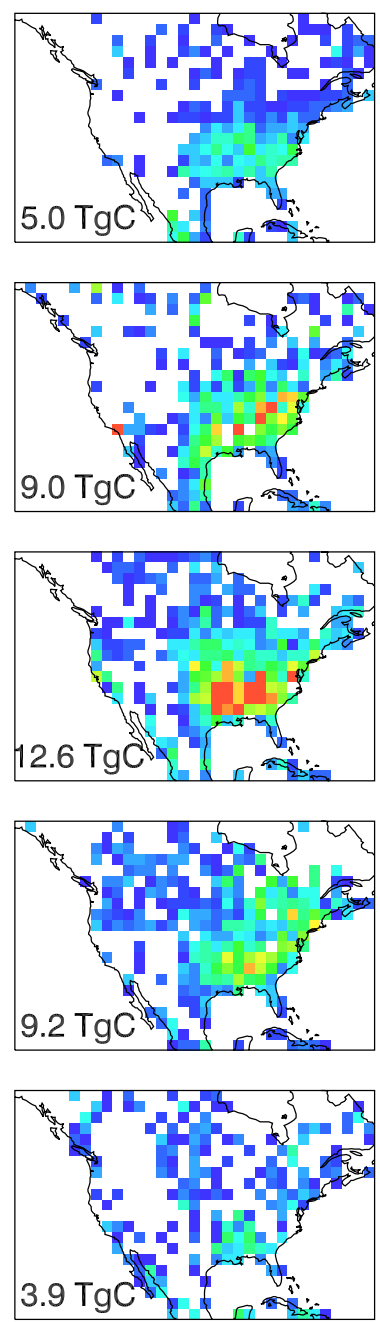
0.0

$$
\begin{array}{lr}
3.5 & 7.0 \\
{\left[10^{12} \text { atoms } \mathrm{C} \mathrm{cm}^{-2} \mathrm{~s}^{-1}\right]}
\end{array}
$$

Figure 7. Monthly mean isoprene emissions $\left(10^{12}\right.$ atom $\left.\mathrm{C} \mathrm{cm}^{-2} \mathrm{~s}^{-1}\right)$ over North America at 1000 1200 LT for May-September 2001 with cloud cover $\leq 40 \%$. (left) MEGAN and (right) GOME isoprene emissions are averaged over the $2^{\circ} \times 2.5^{\circ}$ GEOS-CHEM grid. North American monthly totals are shown inset.

derived isoprene emissions and those predicted by equation (2).

\section{Summary and Discussion}

[36] We analyzed a 6-year (1996-2001) record of HCHO column observations from the GOME satellite instrument, and examined the value of these data as top-down constraints on biogenic VOC emissions. We estimate a $40 \%$ error on the HCHO column retrieval, after removal of a diffuser plate artifact. Clouds are the most important source of error. The resolution of GOME is $40 \times 320 \mathrm{~km}^{2}$, so that cloud contamination is ubiquitous. Higher spatial resolution data $\left(13 \times 24 \mathrm{~km}^{2}\right)$ available from the recently launched Ozone Monitoring Instrument (OMI) aboard the Aura satellite (July 2004) should enable significant reduction of the cloud error by excluding cloudy scenes.

[37] We find that the main source of $\mathrm{HCHO}$ observed by GOME over North America is the oxidation of isoprene. Isoprene forms $\mathrm{HCHO}$ promptly and with high yield. The yield in our GEOS-CHEM CTM mechanism, used to convert GOME HCHO columns to isoprene emission, is 20-30\% lower than in the detailed Master Chemical Mechanism (MCM). Conversely, analysis of in situ isoprene flux and HCHO concentration measurements at the PROPHET site in northern Michigan suggests a $\mathrm{HCHO}$ yield $30 \%$ lower than simulated in GEOS-CHEM. We therefore estimate a $30 \%$ uncertainty in the GEOS-CHEM-derived relationship between $\mathrm{HCHO}$ columns and isoprene emissions. Comparison of the GOME-derived isoprene emissions with in situ flux measurements at the PROPHET site for the 

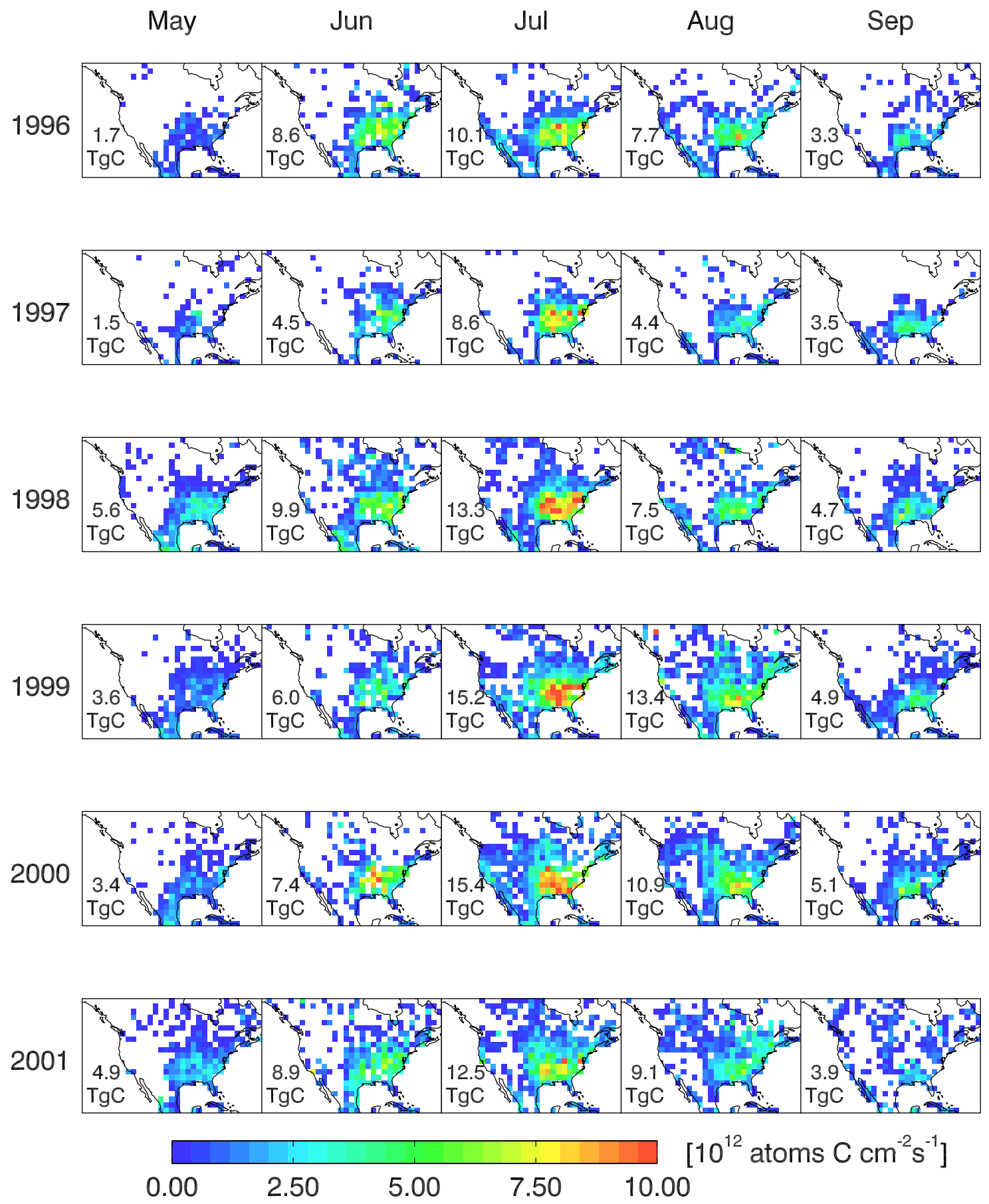

Figure 8. Monthly mean isoprene emissions $\left(10^{12}\right.$ atom $\left.\mathrm{C} \mathrm{cm}^{-2} \mathrm{~s}^{-1}\right)$, as calculated from GOME HCHO slant column data, over North America for May-September 1996-2001. The data are for 1000$1200 \mathrm{LT}$, averaged on a $2^{\circ} \times 2.5^{\circ}$ grid and for cloud cover $\leq 40 \%$. North American monthly totals are shown inset. White areas have no emissions.

length of the 2001 growing season shows good agreement in the seasonal variation of emissions, but poor correlation on a day-to-day basis $(r=0.3)$.

[38] There is a high degree of consistency in continentalscale and seasonal variations of North American isoprene emissions during 2001 derived from GOME and those from the MEGAN bottom-up inventory [Guenther et al., 2005]. GOME is higher than MEGAN by $20-30 \%$ in midsummer and lower by $10 \%$ in the shoulder seasons. Both GOME and
MEGAN show highest emissions in the southeastern United States, but MEGAN has a maximum in the Ozarks while the GOME maximum is farther east.

[39] Examination of the 6-year $\mathrm{HCHO}$ column record from GOME indicates general reproducibility of seasonal and continental-scale patterns from year to year, and consistency in the seasonal onset and shutoff of isoprene emission. Generally, HCHO columns increase in late May, peak in July or August, depending on the year, and decrease 


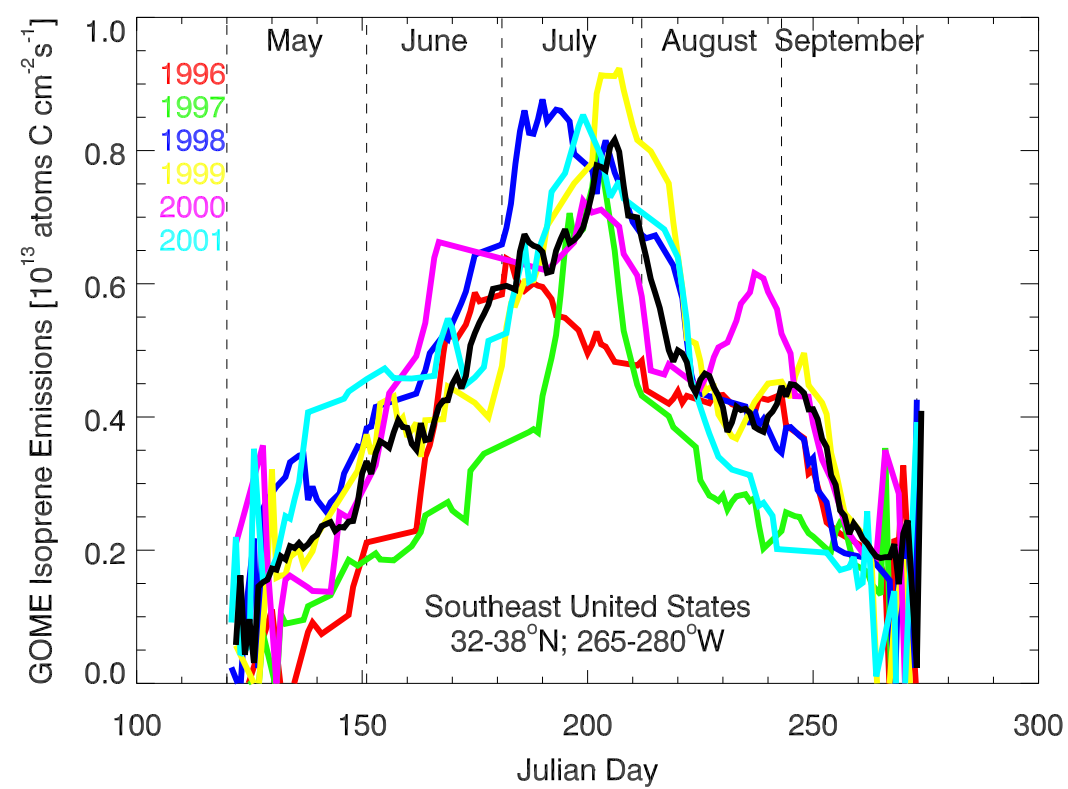

Figure 9. Seasonal variation of isoprene emissions $\left(10^{12}\right.$ atom $\left.\mathrm{C} \mathrm{cm}^{-2} \mathrm{~s}^{-1}\right)$, as calculated from GOME $\mathrm{HCHO}$ column data, over the southeastern United States $\left(32^{\circ}-38^{\circ} \mathrm{N}, 80^{\circ}-95^{\circ} \mathrm{W}\right)$ during the $1996-2001$ growing seasons (May-September). The data have been smoothed with a 10-day running mean. The black line denotes the mean seasonal variation for the 6-year period, and the colored lines show individual years.

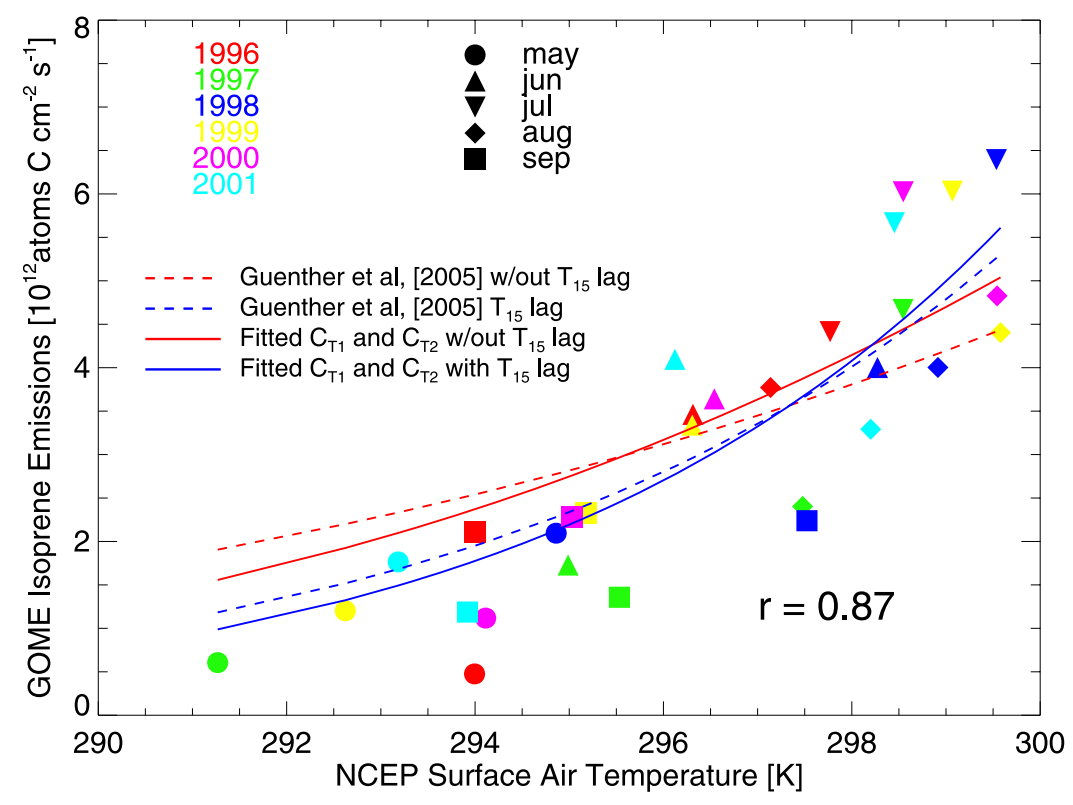

Figure 10. Scatterplot of isoprene emissions $\left(10^{12}\right.$ atom $\left.\mathrm{C} \mathrm{cm}^{-2} \mathrm{~s}^{-1}\right)$, as calculated from GOME HCHO slant column data, versus NCEP surface air temperature $(\mathrm{K})$ over the southeastern United States $\left(32^{\circ}-38^{\circ} \mathrm{N}, 80^{\circ}-95^{\circ} \mathrm{W}\right)$ during May-September $1996-2001$. The Pearson correlation coefficient, $r$, is shown inset. The lines are fits of the MEGAN relationship between surface temperature and isoprene emission $\gamma_{T}\left(C_{T_{1}}, C_{T_{2}}\right)$ [Guenther et al., 2005] (equation (2)), where $\gamma_{T}$ describes isoprene emission as a function of temperature and $C_{T_{1}}=76$ and $C_{T_{2}}=160$ represent activation and deactivation energies that determine the rate at which isoprene changes as a function of temperature. Red lines account only for the dependence of $\gamma_{T}$ on instantaneous temperature, while blue lines also take into account the dependence on temperatures from the past 15 days $T_{15}$ [Petron et al., 2001] (section 3). Dashed lines represent emissions predicted by the empirical model [Guenther et al., 2005], while solid lines represent a simultaneous fit of $C_{T_{1}}$ and $C_{T_{2}}$ to the GOME data. 
rapidly in September. There is significant interannual variation in the seasonal and continental-scale patterns. Examination of the interannual variation in the southeastern United States shows that it is strongly correlated with surface air temperature in a manner consistent with the temperature dependence of isoprene emission in the MEGAN inventory $(r=0.87)$.

[40] Our analysis therefore demonstrates that $\mathrm{HCHO}$ columns observed from space provide valuable top-down constraints on isoprene emission inventories. Data from OMI should provide better data than GOME by virtue of its global daily coverage and higher horizontal resolution. Eventually, these HCHO column data should be used in a formal inverse modeling network with a regional CTM that accounts in a more sophisticated manner for the local relationship between isoprene emission and $\mathrm{HCHO}$ columns. Uncertainty in the isoprene oxidation chemistry, particularly under low- $\mathrm{NO}_{x}$ conditions [Palmer et al., 2003], may at that point represent the principal limitation in the overall approach.

\section{Appendix A: GEOS-CHEM Model Description}

[41] GEOS-CHEM is a global 3-D model of atmospheric composition, applied here to a tropospheric $\mathrm{O}_{3}-\mathrm{NO}_{x}-\mathrm{VOC}$ aerosol simulation for 2001 [Park et al., 2004]. The simulation is driven by assimilated meteorological data from the Goddard Earth Observing System (GEOS-3) at the NASA Global Modeling and Assimilation Office (GMAO). The data have 6-hour temporal resolution (3-hour for surface variables and mixing depths) and $1^{\circ} \times 1^{\circ}$ horizontal resolution. There are 48 sigma vertical levels, extending from the surface to $0.01 \mathrm{hPa}$. The boundary layer up to $2 \mathrm{~km}$ is resolved by nine layers with midpoints at 10 , $45,115,220,370,580,870,1250$, and $1740 \mathrm{~m}$ altitude for a column based at sea level. We use version 6.01 .05 of GEOS-CHEM (www-as.harvard.edu/chemistry/trop/geos) with $2^{\circ} \times 2.5^{\circ}$ horizontal resolution and the native GEOS-3 vertical resolution. The simulation is initialized in January 2001 with standard conditions [Bey et al., 2001]. Proper initialization of $\mathrm{HCHO}$ fields is achieved in a matter of weeks. Anthropogenic emissions in the model are described by Park et al. [2004]. Biogenic VOC emissions of isoprene, monoterpenes, and $\mathrm{MBO}$ are described in the text. There are also relatively large biogenic sources of acetone and methanol, which do not contribute significantly to $\mathrm{HCHO}$ column variability because of their long lifetimes [Palmer et al., 2003]. The chemical mechanism is that of Horowitz et al. [1998] with a number of updates [Bey et al., 2001; Fiore et al., 2002]. It includes a detailed representation of oxidation pathways for five nonmethane hydrocarbons (ethane, propane, lumped $>\mathrm{C}_{3}$ alkanes, lumped $>\mathrm{C}_{2}$ alkenes, and isoprene). Production of $\mathrm{HCHO}$ from $\alpha-$ and $\beta$-pinene are parameterized, as discussed in the main text. Numerical integration of the mechanism is done with a fast Gear solver [Jacobson and Turco, 1994]. Photolysis rates are computed using the Fast-J radiative transfer algorithm [Wild et al., 2000] which includes Rayleigh scattering as well as Mie scattering by clouds. We use monthly averaged UV surface albedo fields from [Herman and Celarier, 1997].
[42] Acknowledgments. We gratefully acknowledge Ted Russell (Georgia Tech), Bill Munger (Harvard), Paul Shepson (Purdue), Lance McCluney (EPA, NC), and Susan Zimmer-Dauphinee (EPA, GA) for providing data and for useful discussions. This work was supported by the NASA Atmospheric Chemistry Modeling and Analysis Program (ACMAP) and by the Atmospheric Chemistry Program of the U.S. National Science Foundation. We thank three anonymous reviewers who provided thorough and thoughtful comments.

\section{References}

Abbot, D. S., P. I. Palmer, R. V. Martin, K. V. Chance, D. J. Jacob, and A. Guenther (2003), Seasonal and interannual variability of North American isoprene emissions as determined by formaldehyde column measurements from space, Geophys. Res. Lett., 30(17), 1886, doi:10.1029/2003GL017336.

Bey, I., et al. (2001), Global modeling of tropospheric chemistry with assimilated meteorology: Model description and evaluation, J. Geophys. Res., 106, 23,073-23,096.

Buermann, W., Y. Wang, J. Dong, L. Zhou, X. Zeng, R. E. Dickinson, C. S. Potter, and R. B. Myneni (2002), Analysis of a multiyear global vegetation leaf area index data set, J. Geophys. Res., 107(D22), 4646, doi:10.1029/2001JD000975.

Chance, K., P. I. Palmer, R. J. D. Spurr, R. V. Martin, T. P. Kurosu, and D. J. Jacob (2000), Satellite observations of formaldehyde over North America from GOME, Geophys. Res. Lett., 27, 3461-3464.

Chin, M., R. B. Rood, S.-J. Lin, J. F. Muller, and A. M. Thompson (2000), Atmospheric sulfur cycle simulated in the global model GOCART: Model description and global properties, J. Geophys. Res., 105, $24,671-24,687$.

Chin, M., et al. (2002), Tropospheric aerosol optical thickness from the GOCART model and comparisons with satellite and sunphotometer measurements, J. Atmos. Sci., 59, 461-483.

Claeys, M., et al. (2004), Formation of secondary organic aerosols through photooxidation of isoprene, Science, 303, 1173-1176.

Fiore, A. M., D. J. Jacob, I. Bey, R. M. Yantosca, B. D. Field, and J. Wilkinson (2002), Background ozone over the United States in summer: Origin and contribution to pollution episodes, J. Geophys. Res., 107(D15), 4275, doi:10.1029/2001JD000982.

Ginoux, P., M. Chin, I. Tegen, J. M. Prospero, B. Holben, O. Dubovik, and S.-J. Lin (2001), Sources and distributions of dust aerosols simulated with the GOCART model, J. Geophys. Res., 106, 20,255-20,274.

Guenther, A., et al. (1995), A global model of natural volatile organic compound emissions, J. Geophys. Res., 100, 8873-8892.

Guenther, A., B. Baugh, G. Brasseur, J. Greenberg, P. Harley, L. Klinger, D. Serca, and L. Vierling (1999), Isoprene emission estimates and uncertanties for the central African EXPRESSO study domain, J. Geophys. Res., 104, 30,625-30,639.

Guenther, A. C., T. Pierce, B. Lamb, P. Harley, and R. Fall (2000), Natural emissions of non-methane volatile organic compounds, carbon monoxide, and oxides of nitrogen from North America, Atmos. Environ., 34, $2205-2230$

Guenther, A. C., T. Karl, P. Harley, C. Wiedinmyer, P. I. Palmer, and C. Geron (2005), Estimates of global terrestrial isoprene emissions using MEGAN (Model of Emissions of Gases and Aerosols from Nature), Atmos. Chem. Phys. Discuss., 6, 107-173.

Hasson, A. S., G. S. Tyndall, and J. J. Orlando (2004), A product yield study of the reaction of $\mathrm{HO}_{2}$ radicals with ethyl peroxy $\left(\mathrm{C}_{2} \mathrm{H}_{5} \mathrm{O}_{2}\right)$, acetyl peroxy $\left(\mathrm{CH}_{3} \mathrm{C}(\mathrm{O}) \mathrm{O}_{2}\right)$, and acetonyl peroxy $\left(\mathrm{CH}_{3} \mathrm{C}(\mathrm{O}) \mathrm{CH}_{2} \mathrm{O}_{2}\right)$ radicals, J. Phys. Chem., 108, 5979-5989.

Herman, J. R., and E. A. Celarier (1997), Earth surface reflectivity climatology at 340-380 nm from TOMS data, J. Geophys. Res., 102, 28,00328,011 .

Hirsch, R. M., and E. J. Gilroy (1984), Methods of fitting a straight line to data: Examples in water resources, Water Res. Bull., 20, 705-711.

Horowitz, L. W., J. Liang, G. M. Gardner, and D. J. Jacob (1998), Export of reactive nitrogen from North America during summertime: Sensitivity to hydrocarbon chemistry, J. Geophys. Res., 103, 13,451-13,476.

Jacobson, M. Z., and R. P. Turco (1994), SMVGEAR: A sparse-matrix, vectorized Gear code for atmospheric models, Atmos. Environ., 28, $273-$ 284.

Jenkin, M. E., S. M. Saunders, V. Wagner, and M. J. Pilling (2003), Protocol for the development of the Master Chemical Mechanism, MCM v3 (part B): Tropospheric degradation of aromatic volatile organic compounds, Atmos. Chem. Phys., 3, 181-193.

Koelemeijer, R. B. A., J. F. de Haan, and P. Stammes (2003), A database of spectral surface reflectivity of the Earth in the range $335-772 \mathrm{~nm}$ derived from 5.5 years of GOME observations, J. Geophys. Res., 108(D2), 4070, doi:10.1029/2002JD002429.

Kurosu, T. P., K. Chance, and R. J. D. Spurr (1999), CRAG-Cloud retrieval algorithm for the European Space Agency's Global Ozone 
Monitoring Experiment, in Proceedings of the European Symposium of Atmospheric Measurements from Space (ESAMS), pp. 513-521, European Space Agency, Noordwijk, Netherlands.

Martin, R. V., et al. (2002), An improved retrieval of tropospheric nitrogen dioxide from GOME, J. Geophys. Res., 107(D20), 4437, doi:10.1029/ 2001JD001027.

Martin, R. V., D. J. Jacob, K. V. Chance, T. P. Kurosu, P. I. Palmer, and M. J Evans (2003), Global inventory of nitrogen oxide emissions constrained by space-based observations of $\mathrm{NO}_{2}$ columns, J. Geophys. Res. 108(D17), 4537, doi:10.1029/2003JD003453.

Martin, R. V., et al. (2004), Evaluation of GOME satellite measurements of tropospheric $\mathrm{NO}_{2}$ and $\mathrm{HCHO}$ using regional data from aircraft campaigns in the southeastern United States, J. Geophys. Res., 109, D24307, doi:10.1029/2004JD004869.

Palmer, P. I., et al. (2001), Air mass factor formulation for spectroscopic measurements from satellites: Application to formaldehyde retrievals from the Global Ozone Monitoring Experiment, J. Geophys. Res., 106, $14,539-14,550$.

Palmer, P. I., D. J. Jacob, A. M. Fiore, R. V. Martin, K. Chance, and T. P. Kurosu (2003), Mapping isoprene emissions over North America using formaldehyde column observations from space, J. Geophys. Res., 108(D6), 4180, doi:10.1029/2002JD002153.

Park, R. J., D. J. Jacob, B. D. Field, R. M. Yantosca, and M. Chin (2004), Natural and transboundary pollution influences on sulfate-nitrate-ammonium aerosols in the United States: Implications for policy, J. Geophys. Res., 109, D15204, doi:10.1029/2003JD004473.

Petron, G., P. Harley, J. Greenberg, and A. Guenther (2001), Seasonal temperature variations influence isoprene emission, Geophys. Res. Lett., 28, $1707-1710$

Pressley, S., B. Lamb, H. Westberg, J. Flaherty, J. Chen, and C. Vogel (2005), Long-term isoprene flux measurements above a northern hardwood forest, J. Geophys. Res., 110, D07301, doi:10.1029/ 2004JD005523.

Richter, A., and T. Wagner (2001), Diffuser plate spectral structures and their influence on GOME slant columns, technical report, Inst. Environ. Phys., Univ. Bremen, Bremen, Germany.

Richter, A., F. Wittrock, A. Ladsttter-Weibenmayaer, and J. P. Burrows (2002), GOME measurements of stratospheric and tropospheric BrO, Adv. Space. Res., 29, 1667-1672.

Sanderson, M. G., C. D. Jones, W. J. Collins, C. E. Johnson, and R. G. Derwent (2003), Effect of climate change on isoprene emissions and surface ozone levels, Geophys. Res. Lett., 30(18), 1936, doi:10.1029/ 2003GL017642.

Saunders, S. M., M. E. Jenkin, R. G. Derwent, and M. J. Pilling (2003), Protocol for the development of the Master Chemical Mechanism, MCM v3 (part A): Tropospheric degradation of non-aromatic volatile organic compounds, Atmos. Chem. Phys., 3, 161-180.

Shim, C., Y. Wang, Y. Choi, P. I. Palmer, D. S. Abbot, and K. Chance (2005), Constraining global isoprene emissions with Global Ozone Monitoring Experiment (GOME) formaldehyde column measurements, J. Geophys. Res., 110, D24301, doi:10.1029/2004JD005629.

Sprengnether, M., K. L. Demerjian, N. M. Donahue, and J. G. Anderson (2002), Product analysis of the $\mathrm{OH}$ oxidation of isoprene and 1,3-butadiene in the presence of NO, J. Geophys. Res., 107(D15), 4268, doi:10.1029/ 2001JD000716.

Sumner, A. L., et al. (2001), A study of formaldehyde chemistry above a forest canopy, J. Geophys. Res., 106, 24,387-24,405.

Thornton, J. A., et al. (2002), Observations of ozone production rates as a function of $\mathrm{NO}_{x}$ abundances and $\mathrm{HO}_{x}$ production rates in the Nashville urban plume, J. Geophys. Res., 107(D12), 4146, doi:10.1029/ 2001JD000932.

Wang, K. Y., and D. E. Shallcross (2000), Modelling terrestrial biogenic isoprene fluxes and their potential impact on global chemical species using a coupled LSM-CTM model, Atmos. Environ., 34, 2909-2925.

Wiedinmyer, C., et al. (2005), Ozarks Isoprene Experiment (OZIE): Measurements and modeling of the "isoprene volcano," J. Geophys. Res., 110, D18307, doi:10.1029/2005JD005800.

Wild, O., X. Zhu, and M. J. Prather (2000), Fast-J: Accurate simulations of in- and below-cloud photolysis in tropospheric chemistry models, J. Atmos. Chem., 37, 245-282.

Zimmerman, P. R., R. B. Chatfield, J. Fishman, and P. J. Crutzen (1978), Estimates on production of $\mathrm{CO}$ and $\mathrm{H}_{2}$ from oxidation of hydrocarbon emissions from vegetation, Geophys. Res. Lett., 5, 679-682.

D. S. Abbot, T.-M. Fu, and D. J. Jacob, Division of Engineering and Applied Sciences, Harvard University, Cambridge, MA 02138, USA.

K. Chance and T. P. Kurosu, Harvard-Smithsonian Center for Astrophysics, 60 Garden Street, Cambridge, MA 02138-1516, USA.

A. Guenther and C. Wiedinmyer, National Center for Atmospheric Research, Boulder, CO 80303, USA.

B. Lamb and S. N. Pressley, Department of Civil and Environmental Engineering, Washington State University, Pullman, WA 99164-5702, USA.

P. I. Palmer, School of Earth and Environment, University of Leeds, Leeds, LS2 9JT, UK. (pip@env.leeds.ac.uk)

M. J. Pilling and J. C. Stanton, Department of Chemistry, University of Leeds, Leeds LS2 9JT, UK.

A. L. Sumner, Battelle, 505 King Avenue, Columbus, OH 43201, USA. 